\title{
GROUP B STREPTOCOCCAL NEONATAL INFECTIONS IN RIO GRANDE DO SUL, BRAZIL
}

\author{
Ernani MIURA(1) \& Maria Cristina MARTIN(1)
}

\begin{abstract}
SUMMARY
Group B Streptococcus is the most common pathogen found in neonatal sepsis in North America.

OBJECTIVES: We describe 15 cases of neonatal infections by Group B Streptococcus (Streptococcus agalactiae) at a Neonatal Intensive Care Unit of a public and teaching hospital.

METHODS: We conducted a study at Hospital de Clínicas de Porto Alegre, from January 1st, 1996 to June 30, 1999. Diagnosis of neonatal infection was established according to the findings of Group B Streptococcus in blood culture associated with alterations resembling sepsis on the basis of clinical picture and laboratory findings.

RESULTS: Fifteen cases of neonatal infections by Group B Streptococcus were detected. Eleven cases consisted of early-onset sepsis, 2 cases of occult bacteremia and 2 cases of late-onset sepsis. Eight cases had septic shock (53\%), 8 cases had pneumonia (53\%), and 4 cases had meningitis (27\%). Fourteen cases were diagnosed from a positive blood culture, and 1 case from evidence of these bacteria in pulmonary anatomopathological examination. Thirteen cases (87\%) were diagnosed before 72 hours of life. We had 3 deaths (20\%), and 3 cases of meningitis developing neurological deficits.

CONCLUSIONS: Streptococcus Group B is one of the most important pathogens in the etiology of early-onset neonatal sepsis at our hospital, with high mortality and morbidity. However, we do not know the incidence of GBS neonatal infections at other hospitals. More data are needed to establish a basis for trials of different strategies to reduce these infections.
\end{abstract}

KEYWORDS: Group B Streptococcus (GBS); Incidence; Neonatal Infection; Sepsis; Meningitis.

\section{INTRODUCTION}

Group B Streptococcus (GBS) is the main cause of perinatal bacterial infections, including postpartum endometritis, chorioamnionitis, urinary tract infection in pregnant women, and systemic/ focal infection in newborns in North America ${ }^{1}$. Neonatal invasive disease is classified into two groups based on its development after birth. Early-onset sepsis occurs on average during the first 24 hours of life, varying from 0 to 6 days. Late-onset sepsis appears between the third and the fourth week of life, varying from 7 days to 3 months. Early-onset sepsis is characterized by tachypnea, apnea, shock, and pneumonia and is frequently mortal. In contrast, the latter is a less severe infectious disease accompanied by meningitis ${ }^{1}$. In the United States, GBS sepsis rate was estimated at 12,000 cases/year, with approximately 1,600 deaths and 1,600 cases of neurological deficits ${ }^{5}$. Since 1992, the Centers for Disease Control (CDC - USA) has recommended application of intrapartum chemoprophylaxis with high doses of penicillin $G$ or intravenous ampicillin in the following cases: (1) GBS in rectovaginal areas in women between 35-37 weeks of pregnancy or (2) in the absence of these bacteria, the presence of high risk factors for the development of neonatal GBS infection (previous birth with GBS infection, bacteriuria with GBS, premature newborn, intrapartum fever, premature rupture of membranes occurring more than
18 hours before delivery). GBS sepsis incidence later decreased to 7,600 cases/year in 1997, with 310 deaths and a cost estimated at US\$ 700 million/year ${ }^{4,5,10}$.

We decided to present fifteen cases of GBS neonatal infections diagnosed at Hospital de Clinicas de Porto Alegre (HCPA) since there are few descriptions of this disease in Brazil.

\section{MATERIAL AND METHODS}

A retrospective study was conducted at the Neonatal Intensive Care Unit of Hospital de Clinicas de Porto Alegre. All newborns who developed GBS in blood cultures, cerebral spinal fluid (CSF), body fluids and pulmonary anatomopathological piece were included in the study. Data were obtained from the Service of Infection Control and the Service of Medical Archives and Statistics. This project was approved by the Commission of Research and Post Graduation and by the Committee of Bioethics of Hospital de Clinicas de Porto Alegre. A peripheral blood sample and central fluid from lumbar puncture were obtained from each patient and submitted to a continuous monitoring system for bacterial development in blood culture called BACTEC fluorescent series system (Bactec ${ }^{\circledR}$ Becton Dickinson Microbiology System) in our Microbiology

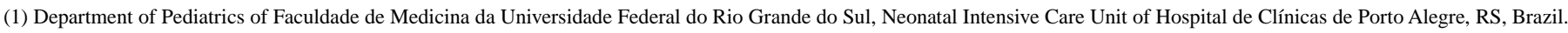

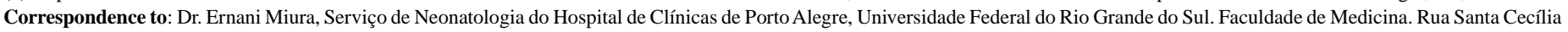
1440, 90420-040 Porto Alegre, RS, Brasil. Fax (0xx51-3324155). Email: emiura.voy@zaz.com.br 
laboratory. The system uses $3 \mathrm{ml}$ of infant blood added to a bottle containing resins that release $\mathrm{CO}_{2}$ from infecting bacteria detected by an infrared sensor which makes it fluorescent. In positive samples, the microrganism was identified by colony morphology, hemolysis, and the CAMP test for identification of Streptococcus agalactiae ${ }^{2,8}$. CSF and body fluids were cultured on a Blood-Agar plate and positive samples were processed as described for GBS identification ${ }^{8}$.

In our study, we considered: (1) sepsis as the pure development of GBS in blood culture with clinical signs of infection which may vary from fever, respiratory distress, convulsions, hypoactivity, or apnea, associated with changes in laboratory parameters such as total neutrophil count and immature to total neutrophil ratio (neutropenia less than 1,500/ $\mathrm{mm}^{3}$, immature to total neutrophils ratio higher than 0.2); (2) development of GBS meningitis in CSF or more than $60 \%$ of neutrophils with more than 30 leukocytes $/ \mathrm{mm}^{3}$; (3) bronchopneumonia as respiratory distress with pulmonary radiographic findings of diffused or confluent gross opacifications; and blood culture with GBS.

\section{RESULTS}

Over a period of 3.6 years, we diagnosed 15 cases of neonatal GBS infection; of these, 14 cases had positive blood culture and one had pulmonary anatomopathological findings. In two cases, the patients presented without symptoms: one newborn had occult bacteremia and did not received antibiotics; the other had fever, bacteremia and conjunctivitis, being treated with topical gentamicin.

Mean birth weight was 2,710 \pm 745 grams (1,240-4,050 grams) and mean gestational age was $36.9 \pm 3.6$ weeks, with the following distribution: a case with 29 weeks, 5 cases with less than 35 weeks, and 9 cases with more than 38 weeks. Average time in early-onset sepsis diagnosis was 1 day (0-15), distributed as it follows: 5 cases showed signs of infection immediately after birth, 3 patients were diagnosed on the first day, 3 on the second day, 2 on the third day, one on the $11^{\text {th }}$ day, and one on the $15^{\text {th }}$ day of life. Therefore, we had 13 cases of early-onset infections with an incidence of $1 / 1,000$ live births $(13,000$ live births in 3.5 years) and 2 cases of late-onset infections.

Through medical chart review, we found 6 cases with maternal risk factors (40\%): 5 cases of premature labor, 3 cases of premature rupture of membranes, and 2 cases of urinary tract infection. The clinical picture of sepsis was accompanied by the following complications: 7 patients needed mechanical ventilation, 3 needed concentrated, and 4 had convulsions during the early stage of sepsis. Four cases of sepsis were associated with meningitis, 8 had chest radiographs showing bronchopneumonia, and 3 cases had characteristic findings of hyaline membrane disease. We treated 10 patients with ampicillin plus gentamicin for 10 days, 3 patients with crystalline penicillin $G$ plus gentamicin, and 4 patients with the combination of vancomycin, cefotaxime plus amikacin according of our second scheme of presumptive antibiotic therapy. The following sequels were seen: one patient had periventricular leukomalacia, 2 patients had persistent convulsions, and one patient had associated neurosensory hearing loss. Three deaths occurred in premature infants. One died with 12 hours of life of septic shock and pulmonary hypertension, one died with 48 hours of life, and the third with three days of life, both newborns with pulmonary hypertension and multiple organ failure.
Table 1

Demographic characteristics of neonatal infection by Group B Streptococcus

\begin{tabular}{ll}
\hline Demographic characteristics & Number of cases $(\%) \mathrm{n}=15$ \\
\hline Weight at birth (grams) & $2710 \pm 745$ \\
Mean $\pm \mathrm{S} \Delta$ & \\
\hline Pediatric gestational age (weeks) & $36.9 \pm 3.6$ \\
Mean $\pm \mathrm{S} \Delta$ & \\
\hline Maternal age (years) & $23.8(19-34)$ \\
Mean & \\
\hline Sex & Male $7(47 \%)$ \\
\hline Fifth minute Apgar score & Female $8(53 \%)$ \\
Mean \pm S $\Delta$ & $8.7 \pm 0.8$ \\
\hline Septic shock & $8(53 \%)$ \\
\hline Bronchopneumonia & $8(53 \%)$ \\
\hline Meningitis & $4(27 \%)$ \\
\hline Early-onset sepsis & $11(73 \%)$ \\
Late-onset sepsis & $2(13 \%)$ \\
Occult bacteremia & $2(13 \%)$ \\
\hline Onset of the infection (days) & 1 \\
Mean & $(0-15)$ \\
\hline Deaths & $3(20 \%)$ \\
\hline
\end{tabular}

\section{DISCUSSION}

There are some studies describing the role of perinatal GBS infection in Brazil and South America. The Brazilian studies are about the incidence of colonization in pregnant women and their newborns. BENCHETRIT at al. ${ }^{3}$ in 1982, for the first time in Brazil, detected GBS in 22 of 86 pregnant women $(26 \%)$ and in 12 of their 78 newborn infants $(15 \%)$. SKLOVSKY at al. ${ }^{14}$ in 1983 in Porto Alegre described 4 cases of GBS in 67 pregnant women $(6 \%)$ and just one case of their newborn infants (1.5\%). SMÂNIA JUNIOR et al. ${ }^{15}$ in 1986 detected in Florianópolis 34 cases in 135 pregnant women $(25 \%)$ and 16 cases in their newborns (12\%). There were two other studies in South America reporting a low incidence of GBS colonization at the end of pregnacy. In 1995, in Londrina, MOCELIN et al. ${ }^{9}$ detected 15 cases in 100 pregnant women (15\%) and COLLINS et al. ${ }^{6}$ detected a prevalence of $6 \%$ of vaginal colonization by GBS in Peruvian pregnant women. These data represent a low incidence compared to data reported for American women whose prevalence is around $35 \%{ }^{1,4,5}$. There is no report of the role of GBS neonatal infections in Brazil. One study similar to ours was reported by SARRUBI et al. ${ }^{12}$ in Buenos Aires, covering the period from 1984 to 1997, in which the authors detected 76 cases of neonatal infections by GBS in 83,859 newborns, corresponding to an attack rate of 0.9 cases/ 1,000 live newborns. These data were similar to our NICU and with the same attack-rate for GBS early-onset sepsis of 1.0/1,000 live newborns. 
In the United States, intrapartum chemoprophylaxis reduced earlyonset sepsis attack rate to levels between 0.72 and 5.5/1,000 live newborn infants. In premature infants weighing less than 1,500 grams the attack rate is higher $(7.6$ and $26.2 / 1,000)$. In newborns at term this rate is lower ( 0.5 and 1.5/1,000 live births) although $80 \%$ of the cases of early-onset sepsis occur in term newborn infants. Mortality in the United States ranges from $2 \%$ to $8 \%$ in term newborn infants and from $25 \%$ to $30 \%$ in premature newborns ${ }^{1,5,10}$. STOLL et al. ${ }^{16}$ reported that GBS is currently the most important pathogen in early-onset sepsis at 12 centers of neonatal intensive care with a $31 \%$ incidence. In contrast, two studies published outside the United States and Canada showed a low incidence of perinatal GBS infection. KALLIOLA et al. ${ }^{7}$ reported 398 cases of early-onset GBS neonatal infection over a period of 10 years, with an incidence of $0.63 / 1,000$ live births in Finland, with a case fatality rate of $9.2 \%$. They diagnosed sepsis in $77 \%$ of cases, meningitis in $17 \%$ of cases, and pneumonia in $3 \%$ of cases. MOSES et al. ${ }^{11}$ described data of 41 cases of GBS early-onset sepsis that occurred from 1985 to 1996 in Oxford with a low incidence of 0.5 per 1,000 live births (95\% CI 0.4-0.7), and with a $19.5 \%$ mortality rate. All deaths occurred in preterm babies. They had 22 cases of sepsis, 13 of pneumonia, and 6 of meningitis. These results outside North America are similar to ours with an attack rate of $1.0 /$ 1,000 live newborns. However, these results may be unreliable because our hospital receives high risk pregnancies with an adverse pregnancy outcome.

Intrapartum chemoprophylaxis is very efficient and resulted in a reduction from 1,600 to 310 deaths per year in the United States from 1993 to $1995^{5}$, although some difficulties occurred in practice. The screening is not always accepted by the obstetrician or by the pregnant women. Moreover, the use of antibiotics has untoward effects like allergic reactions, increase in bacterial resistance, increase of infections by gramnegative bacteria, and secondary colitis ${ }^{13}$. Besides, it is known that intrapartum antibiotics administered to pregnant women do not change the course of the infection in early-onset sepsis by GBS in term $\mathrm{NB}^{4}$. It is important to emphasize that no obstetric risk factors were detected in approximately $25 \%$ to $30 \%$ of infected babies and about $30 \%$ of earlyonset sepsis cases and $10 \%$ of deaths are not covered by intrapartum chemoprophylaxis ${ }^{4,10}$. When these intrapartum risk factors are present we should investigate the infection and treat the infant. Definitive diagnosis is confirmed by culture examination with development of GBS and its serotype can be identified at reference laboratories. Treatment of newborns with a presumptive diagnosis is based on the combination of penicillin $\mathrm{G}$ or ampicillin with gentamicin. After confirmation of GBS in culture, penicillin $\mathrm{G}$ or ampicillin treatment alone is adopted with discontinuation of gentamicin. Although the optimum dosage is unknown, it is recommended to administer 400,000 UI/kg/day of penicillin $\mathrm{G}$ or $300 \mathrm{mg} / \mathrm{kg} /$ day of ampicillin, I.V. for 10 days in sepsis and for 14-21 days in meningitis ${ }^{1}$.

\section{CONCLUSION}

Group B Streptococcus is one of the most important patohogens in the etiology of early-onset neonatal sepsis at our hospital, with high mortality and morbidity. However we do not know the incidence of GBS neonatal infections at other hospitals. More data are needed showing the importance of GBS in the etiology of neonatal sepsis to establish different strategies for its reduction.

\section{RESUMO}

\section{Infecção neonatal por Streptococcus do grupo B no Rio Grande do Sul, Brasil}

FUNDAMENTOS: Streptococcus do grupo B é o principal agente etiológico responsável pela sepse neonatal na América do Norte.

OBJETIVOS: Relatar 15 casos de infecção neonatal por Streptococcus do grupo B (Streptococus agalactiae) ocorridos na Unidade de Tratamento Intensivo Neonatal de um hospital público e universitário.

MÉTODO: O estudo foi realizado no Hospital de Clínicas de Porto Alegre no período de $1^{\circ}$ de janeiro de 1996 a 30 de junho de 1999 . O diagnóstico de infecção neonatal foi feito a partir do isolamento e identificação de Streptococcus do grupo B em hemocultura combinado com alterações clínicas e laboratoriais sugestivas de sepse.

RESULTADOS: Foram detectados quinze casos de infecção neonatal por Streptococcus do grupo B, sendo onze casos de sepse de origem precoce, dois casos de bacteremia oculta e dois casos de sepse de origem tardia. Oito casos tiveram choque séptico (53\%), oito casos com pneumonia (53\%) e quatro casos com meningite (27\%). Quatorze casos foram diagnosticados a partir da hemocultura e um caso através da presença desta bactéria no exame anátomo-patológico do pulmão. Treze casos (87\%) foram diagnosticados antes de três dias de vida. Ocorreram três óbitos $(20 \%)$ e três pacientes com meningite ficaram com seqüelas neurológicas.

CONCLUSÃO: O Streptococcus do Grupo B é uma das bactérias mais importantes na etiologia da sepse neonatal de início precoce em nosso hospital com elevada mortalidade e também com elevada morbidade. Entretanto, não se conhece sua incidência em outros hospitais. São necesssários outros estudos para determinar seu papel na sepse neonatal e assim estabelecer diferentes estratégias para sua redução.

\section{REFERENCES}

1. AMERICAN ACADEMY OF PEDIATRICS - Group B streptococcal infections. In PICKERING, L.K., ed. Red Book: report of the Committee on Infectious Diseases. 25. ed. Elk Grover Village, American Academy of Pediatrics, 2000. p. 537-542.

2. ANDERSON, J.D.; TROMBLEY, C. \& CIMOLAI, N. - Assessment of the BACTEC NR660 blood culture system for the detection of bacteremia in young children. J. clin. Microbiol., 27: 721-723, 1989.

3. BENCHETRIT, L.C.; FRACALANZZA, S.E.L.; PEREGRINO, H.; CAMELO, A.A. \& SANCHES, L.A. - Carriage of Streptococcus agalactiae in women and neonates and distribution of serological types: a study in Brazil. J. clin. Microbiol., 15: 787-790, 1982.

4. BROMBERGER, P.; LAWRENCE, J.M.; BRAUN, D. et al. - The influence of intrapartum antibiotics on the clinical spectrum of early-onset group B streptococcal infection in term infants. Pediatrics, 106: 244-250, 2000.

5. CENTERS FOR DISEASE CONTROL - Decreasing incidence of perinatal group B streptococcal disease: United States, 1993-1995. M.M.W.R., 46(21): 473-477, 1997.

6. COLLINS, T.S.; CALDERON, M.; GILMAN, R.H.; VIVAR, A. \& CHARACHE, P. Group B streptococcal colonization in a developing country: its association with sexually transmitted disease and socioeconomic factors. Amer. J. trop. Med. Hyg., 59: 633-636, 1998. 
7. KALLIOLA, S.; VUOPIO-VARKILA, J.; TAKALA, A.K. \& ESKOLA, J. - Neonatal group B streptococcal disease in Finland: a ten-year nationwide study. Pediat. infect. Dis. J., 18: 806-810, 1999.

8. LARSEN, H.S. - Streptococcaceae. In: MAHON C.R. \& MANUSELIS, G. Textbook of diagnostic Microbiology. 2. ed. Philadelphia, W. B. Saunders, 2000. p. 345-358.

9. MOCELIN, C.O.; CARVALHO, D.A.A.F.; BRITES, C. et al. - Isolamento de Streptococcus agalactiae de gestantes na região Londrina-PR. Rev. bras. Ginec. Obstet., 17: 915-918, 1995.

10. MORITA, J.Y.; O‘BRIEN, K.L. \& SCHUCHAT, A. - Prevention of perinatal group B streptococcal infections. Pediat. infect. Dis. J., 18: 278-280, 1999.

11. MOSES, L.M.; HEATH, P.T.; WILKINSON, A.R.; JEFFERY, H.E. \& ISAACS, D. Early onset group B streptococcal neonatal infection in Oxford 1985-96. Arch. Dis. Child Fetal-Neonatal, 79: F148-149, 1988.
12. SARRUBI, M.A.; DINERSTEIN, N.A; PAGANINI, H. et al. - Bacteremias neonatales por estreptococo $\beta$ hemolitico del grupo B: trece años de experiencia. Rev. Hosp. Matern. Infant. Ramon Sarda, 19(2): 52-59, 2000.

13. SCHUCHAT, A.- Neonatal group B streptococcal disease: screening and prevention. New Engl. J. Med., 343: 209-210, 2000

14. SKLOVSKY, E.; BERTSCHINGER, B.; BARCELOS, S.H. \& PROCIANOY, R.S. Colonização materna e do recém-nascido por estreptococo do grupo B de Lancefield. Rev. HCPA Fac. Med. Univ. Fed. Rio Gr. Sul, 3: 107-108, 1983.

15. SMÂNIA JUNIOR, A.; BENCHETRIT, L.C.; SMÂNIA, E.F.A. \& FRACALANZZA, S.E.L. - Isolamento do estreptococos do grupo B, de gestantes e neonatos, em Florianópolis, Santa Catarina. Rev. bras. Anal. Clín., 18: 103-108, 1986.

16. STOLL, B.J.; GORDON, T.; KORONES, S.B. et al. - Early-onset sepsis in very low birth weight neonates: a report from the National Institute of Child Health and Human Development Neonatal Research Network. J. Pediat., 129: 72-80, 1996.

Received: 2 April 2001

Accepted: 22 August 2001 